\title{
Application of "The nature of science" box event examples to middle school seventh grade students
}

\author{
Özlem Afacan ${ }^{1}$, Demet Şener Çanli ${ }^{2}$ \\ ${ }^{1}$ Department of Science Education, Kırşehir Ahi Evran University, Turkey \\ ${ }^{2}$ Science Teacher, Ministry of Education, Turkey
}

\begin{tabular}{l}
\hline Article Info \\
\hline Article history: \\
Received Mar 16, 2019 \\
Revised Apr 10, 2019 \\
Accepted May 18, 2019 \\
\hline
\end{tabular}

Keywords:

Box activity examples

School

Student

The nature of science

\begin{abstract}
Previous study on the nature of science indicated that the use of activities is essential and important in the teaching of the nature of science subjects. The aim of the research is to develop alternative activities for helping students in the seventh grade of middle school develop their views on the nature of science and for better teaching the nature of science. In this study, four different activities suitable for middle school seventh class achievements which are also related to the nature of science were developed and worksheets related to those activities were prepared. The activities and worksheets were examined by two science education experts and necessary arrangements were made in line with their opinions. These events are called; "mystery candle inbox", "following trail", "mystery in box", and "Colorful lights" activity. This study was designed according to case study settings from qualitative research methods. The research group consists of 27 students who are in the seventh grade of a middle school in Kırşehir. When the activities are being carried out, students filled in worksheets for each activity. The worksheets were analyzed by content analysis method. At the end of the research, it was determined that the designed and applied the nature of science activities have a positive effect on the development of the students' opinions about the nature of science.
\end{abstract}

Copyright (C) 2019 Institute of Advanced Engineering and Science. All rights reserved.

Corresponding Author:

Özlem Afacan,

Department of Science Education,

Kırşehir Ahi Evran University,

Bağbaşı Road, Sahit Kurutluoglu Street, Number 100, 40100, Kırşehir, Turkey.

Email: ozlemafacan2005@gmail.com

\section{INTRODUCTION}

Understanding the nature of science is important in structuring scientific knowledge. To evaluate the development of knowledge in the historical process and its factors in social acceptance, recognizing and understanding how the nature of science has a conceptual phenomenon can help to use it more effectively in education.

The nature of science and research into science education began in the late 19th century of Mach and Dewey's study in the early 20th century [1]. At the beginning of the 1960s, Joseph Schwab mentioned that the structure of science was a discipline and tried to develop curricula and learning strategies related to science. This subject which was interested in Schwab at first, Coben [2] described as the nature of science later. The first article in this field was published by Merrit Kimball in 1967, and the first book was published in 1969 by James Robinson, an educator. Later on, increasing studies in this area made it necessary to make a definition about the nature of science.

Although the nature of science has been described in many different ways, it has been evaluated as values and assumptions for the development of scientific knowledge [3].

Some features of the nature of science are explained as [4-13]: 
a. The tentative nature of scientific knowledge: Scientific information is reliable but not certain. Scientific information can be changed or renewed over time with new data, new observation and reinterpretation of existing data and observations.

b. The emprical nature of scientific knowledge: Scientific knowledge is based on the observation of nature and emerges from them. However, scientific knowledge cannot be attained by observing nature most of the time. In cases where it cannot be observed directly, scientific knowledge is based on experiments. Scientific information includes logical, mathematical and experimental inferences.

c. Subjectivity of scientific knowledge: Scientific knowledge remains attached to objectivity, while being influenced by all the backgrounds, personal experiences, perspectives and prejudices of scientists.

d. The creative and imaginative nature of scientific knowledge: Scientific knowledge can improve itself depending on creative thinking. Scientists use their imagination and creativity in creating scientific knowledge.

e. Observation-inference in science: There is a difference between observation and inference. Science is dependent on observations and observations and the implications of interpretation.

f. Scientific theories and laws: The theories and laws differ from scientific knowledge. While laws are used to present scientific facts, theories are used to explain scientific facts.

g. The social and cultural embeddedness of scientific knowledge: Scientific knowledge is socially and culturally established. Scientific knowledge is influenced by the social and cultural values of the society.

Until today although there is no common definition of what science is, there are some common values about the nature of science. According to this understanding that we can define as the nature of science, scientific knowledge may change over time or renewable, during this change, scientific knowledge depends on objectivity while developing it self on the basis of creative thinking, at the same time, it carries the effects of the society from which it emerges, and finally, exposes or explains the events with theoretical formation and factual descriptions [5, 8, 10, 14-19].

The primary objectives of science education are to develop an adequate understanding of the nature of science and the development of science literacy. Research shows that there are deficiencies in the understanding of the nature of science in all students from kindergarten to 12th grade as well as teachers [8], $[13,18-24]$. Adopting the concepts of the nature of science in developing science literacy and developing an understanding of them [23].

Considering the modern science and educational practices, learning the nature of science is one of the most important goals of the reform movements. It is also seen in the innovation initiatives prepared by the Ministry of National Education that the nature of science is very important for students to become science literate individuals [25]. So the views of the Ministry of National Education that curricula and practices for the development of science literacy should be included in the recent reform movements have accelerated the studies conducted in this field.

Teachers had a limited number of professional activities so that their students could develop the concepts of nature of science. In this context, there has been an effort focusing on motivating students understand and learn the nature of science better by the examples of developed activities [10].

With recent changes in the Turkish education system, the concept of "the nature of science" has been introduced in science curricula, there still are difficulties been experienced about integrating it into every unit taught in science $[17,26]$.

Activities that will integrate the nature of science with subject acquisitions offer an effective solution for the needs of the lessons. In this way, while students learn the subject gains, on the other hand, by emphasizing the concepts of nature of science, they are provided to develop their own understanding of the nature of science [27].

In order to overcome this deficiency, it is the basis of this research to reproduce the characteristics of the nature of science with examples of alternative activities aimed at teaching secondary school students. The activities mentioned here are designed to be an important source for teachers and other researchers in accordance with the objectives and objectives specified in the secondary school science curriculum. In addition, small changes in activities can be applied to different disciplines and issues.

In order to solve this deficiency, it is the basis of this research to reproduce examples of alternative activities aimed at teaching secondary school students the characteristics of the nature of science. The activities mentioned are designed to be an important source for teachers and other researchers in accordance with the objectives and objectives specified in the secondary school science curriculum.

The aim of this research is to determine the status of students by developing alternative activities that will help to improve the views of the seventh grade students about the nature of science and to better teach the nature of science.

Int. J. Eval. \& Res. Educ. Vol. 8, No. 2, June 2019: 221 - 228 


\section{RESEARCH METHOD}

The research is the case study included in the qualitative research designs. Case study is a research method which running a current phenomenon in its real life frame, the boundaries between the case and its content are not clear and used in cases where more than one evidence or data source is available [28].

In the research, the designed activities were applied to 27,7 th grade students in a public school in Kırşehir province during the second semester of 2016/2017 academic year.

The working papers prepared for the implementation of the activities were carried out by Doğan et al [29]. After the study papers were prepared, they were examined by two experts. A pilot study has been carried out with the seventh grade students of 27 students who are in a different and then the necessary works have been done.

\subsection{Design of nature of science teaching activities}

In this study, six different activities related to the nature of science were developed for 7 th grade of secondary school students by researchers. The prepared activities were examined by two science education experts and the necessary arrangements were made in line with their opinions. The pilot applications of activities were applied with 27 students studying in 7th grade in the first semester of 2016/2017 academic year. At the end of the pilot application, arrangements were made.

Black box activities which were designed Lederman and Khalick [30] are adapted by researcher. Black box events provide experiences with students similar to scientists' characters. Students try to understand the events how they work. Students make observations, collect data, make inferences and propose hypotheses to explain the data. Then they make predictions based on these hypotheses. Develop ways to test them (There is no need to limit these pathways to controlled experiments). Based on their tests, they decide whether the hypotheses are appropriate or not [30].

The exemplary activities given in the same way do not have to be applied in the same way. If necessary, changes can be made depending on the conditions of your class, the interests of the students and the appropriate time [30].

\subsubsection{Nature of science teaching activities}

In this study, only one activity was given. It could be found more information about these activities in the other references [27, 31].

Activity 1 : Mysterious candle in the box

Topic : Change of state of matter

Acquisition : The student makes experiments that can change the effect of heat and makes inferences based on the data obtained.

With this activity; the difference between observation and inference, the interchange ability of scientific knowledge, scientific knowledge based on experimentation, scientific knowledge as a part of the extraction of people, imagination and creativity aims to gain features.

Implementation of the activity

The mechanism shown in Figure 1 is prepared in advance and brought to class so that it can be seen by every student. Students are divided into random groups of 3-4 people. The candle in the box is burnt. The students observe the candle flame from below the eye level, but they cannot see inside the box. Observation continues for a while. Students observe that the candle in the box does not melt or disappear or shrink. Ask students what might happen in the box.

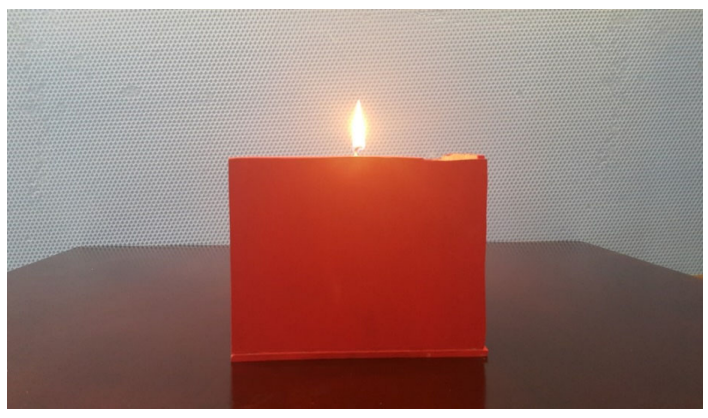

Figure 1. Outside the box. 
Students fill out the worksheet to draw their ideas about what might happen in the box and to make an explanation of what process might happen in the box. They make an explanation of the idea of the activity with their drawings in front of the class. Teacher draws attention to the different ideas and answers of the students to emphasize the place of imagination and creativity in the production of scientific knowledge.

Students are asked to compare their group with the other group models. Teacher asks them if their ideas have changed. The argument is focused around whether scientific information can be changed with new data, interpretations and insights. Inside of the box is shown to all groups after completing their drawings. Students observe that candle is placed in a glass of water inside the box (Figure 2 and Figure 3 ).

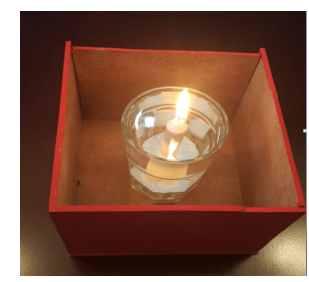

Figure 2. Inside the box

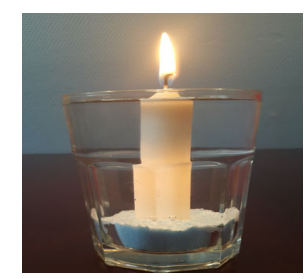

Figure3. Inside the glass

Then, questions are asked to stimulate students' thinking about the topic: Why does not the candle melt in the water?; Will the candle never melt?; Will this activity give the same results for other liquids?

Teacher points out the similarities of the activity and scientists' works. They are asked to respond to other questions on the worksheets. Students' knowledge about the characteristics of the nature of science which are tentativeness of scientific knowledge, the difference between observation and inference, part of the inference, imagination, and creativity of humans, and based on experiments are controlled [31].

\subsection{Analysis of data}

The working papers were analyzed by content analysis in order to determine the students' activities during the application.

\section{RESULTS}

Mysterious candle in the box activities drawings of what students may be inside the box for each group shows in Figure 4.

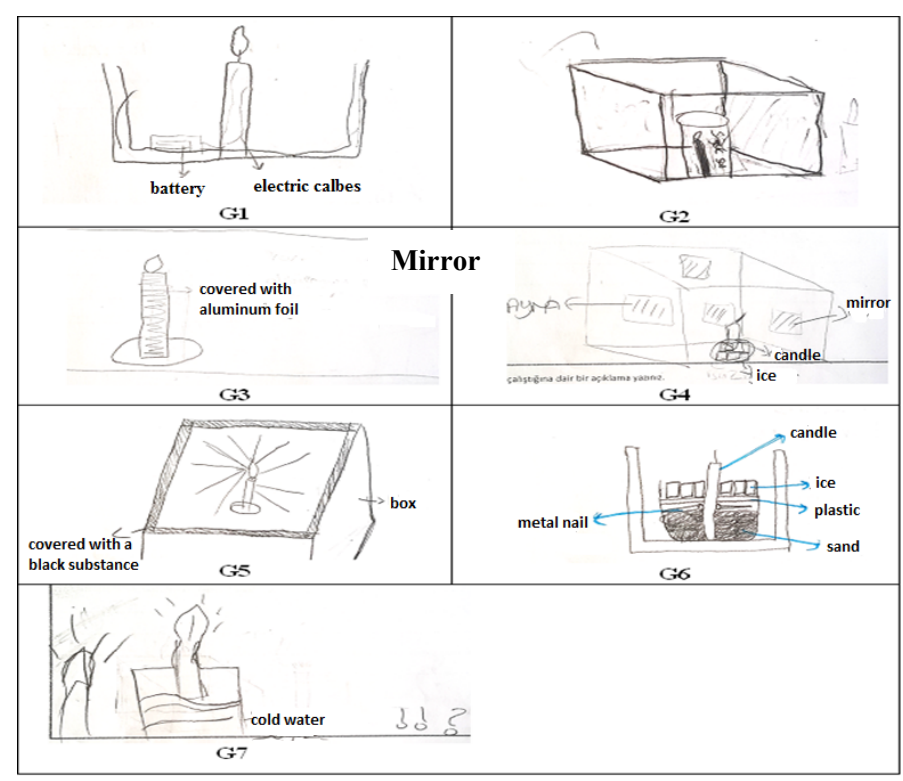

Figure 4. Mysterious candle in the box activities drawings of what students may be inside the box for each group

Int. J. Eval. \& Res. Educ. Vol. 8, No. 2, June 2019: 221 - 228 
In the drawing of the group G1, it is seen that the candle inside the box is connected to a battery by electric cables. The drawings drawn by the G2 group include a glass and cold water in the box. In the G3 drawings, the candle inside the box appears to be covered with aluminum foil. The group G4 indicated ice on the underside of the candle and mirrors on the sides of the box. The interior of the box is covered with a black substance in G5's drawings. In the drawing of G6 there are sand, nails plastic and ice around the candle inside the box. In the drawing of G7 it is seen that there is cold water inside the box. The explanations of the students are classified as in Table 1.

Table 1.Distribution of student descriptions by groups

\begin{tabular}{lc}
\hline Explanations on what can be in the box & Responding group/Groups \\
\hline The candle burns off without being electric & $\mathrm{G} 1$ \\
$\begin{array}{l}\text { The candle is in the cold water, so the candle doesn't melt } \\
\text { Because the candle is covered with aluminum foil, candle late melting }\end{array}$ & $\mathrm{G} 2, \mathrm{G} 7$ \\
$\begin{array}{l}\text { The candles in the box may not reflect the mirror and the melting candle may } \\
\text { not melt by freezing the ice }\end{array}$ & $\mathrm{G} 4$ \\
$\begin{array}{l}\text { It absorbs the heat emitted by the light and reduces the heat in the } \\
\text { environment, so the melting time of the candle is prolonged. }\end{array}$ & $\mathrm{G} 5$ \\
$\begin{array}{l}\text { Soil, nails, plastic and ice, the device provides the temperature balance of the } \\
\text { candle causes late melting }\end{array}$ & $\mathrm{G} 6$
\end{tabular}

As seen in Table 1, groups G2 and G7 think that the candle in the box is in cold water and therefore the candle does not melt.The G1 group says that there is an electrical system in the box. The G3 group suggested that the candle was covered with aluminum foil. The G4 group thinks that the mirrors and ice in the box prevent the candle from melting. G5 indicates that the inside of the box is covered with a black substance and this black substance reduces the heat emitted by the light, thus extending the melting time of the candle.

For the question of "Do you think that imagination and creativity are important components for production of scientific knowledge?"All groups said "Yes, we think it is important". When teaching with the activity, students stated that imagination and creativity were important in the production of scientific knowledge.

The question of "How do you think an event that scientists can observe but do not know the details? "The answers to the question are classified as follows.

As shown in Table 2, three groups (G1, G5, and G6) said the scientists use imagination. G2 and G4 stated that the scientists make prediction, G2 and G5 said that the scientists generate ideas, G3 and G7 groups said that scientists think and G1 and G5 said that the scientists make assumption. One group examined the scientists (G2) and uses the creativity (G3) have produced ideas. When teachings with the activity, the students explain the events that scientists can observe but do not know the details they stated that imagination and creativity were important.

Table 2. The thoughts and distribution of the groups about how scientists can observe but explainan event that they do not know the details

\begin{tabular}{cccccccc}
\hline Groups & $\begin{array}{c}\text { Make } \\
\text { Assumption }\end{array}$ & $\begin{array}{c}\text { Make } \\
\text { prediction }\end{array}$ & Examine & $\begin{array}{c}\text { To } \\
\text { generatedeas }\end{array}$ & $\begin{array}{c}\text { Use your } \\
\text { imagination }\end{array}$ & $\begin{array}{c}\text { Use your } \\
\text { creative }\end{array}$ & Thinking \\
\hline G1 & + & + & + & + & + & & + \\
G2 & & + & + & & & + & + \\
G3 & & + & & & + & & \\
G4 & & & & + & + & & + \\
G5 & + & & & & + & & + \\
G6 & & & & & & & \\
G7 & & & & & &
\end{tabular}

The question of "Do you think that imagination and creativity are important in the production of scientific knowledge?" All of groups said " yes we think it is important".

The answers given to the "Did your ideas change after you saw the drawings of other groups? Do you think that scientists' ideas can change in the light of new data, new perspectives and interpretations? Question are as follows. 
As shown in Table 3, G2, G3, G5, G7 indicated that their ideas did not change when they saw the drawing of other groups.G4 and G6 groups are the opinions that their ideas have not changed but some teams' ideas are logical. The G1 group explained that their ideas changed.

Table 3. When you see other drawings of groups' distribution of the changes of their ideas by groups

\begin{tabular}{lc}
\hline Group'sexplain & Responding group/Groups \\
\hline Our idea has changed, Our idea changes & $\mathrm{G} 1$ \\
Our idea hasn't changed & $\mathrm{G} 2, \mathrm{G} 3, \mathrm{G} 5, \mathrm{G} 7$ \\
Our idea has not changed, but the idea of this team was also logical & $\mathrm{G} 4, \mathrm{G} 6$
\end{tabular}

\section{DISCUSSION}

Designing alternative activities for teaching science will help the seventh grade students to develop their views on the nature of science and to develop better ways to teach the nature of science. The characteristics of the nature of science are tentativeness of scientific knowledge, the role of imagination and creativity in the production of scientific knowledge, the subjectivity of scientific knowledge, the difference between observation and inference, the influence of social and cultural values on scientific knowledge, and depending on scientific data.

The activity developed by the researchers was easy to implement into the real classroom practice, and no problem was encountered. This shows that these type of box activities can be easily implemented by other teachers. During the implementation of the activity, group work was frequently conducted, and the students were encouraged to work together and exchange ideas. It is thought that the students will benefit from the concepts related to the nature of science.

The box activity which was designed in this study; is mainly focused on teaching students several sides of the nature of science like being based on observation and deduction, and its experimental, imaginative and creative nature.

Beside the experimental studies on the nature of science have made a significant contribution to the development of students' views on the nature of science [7-9, 32, 33], the box activities also produced positives effects on students' views on the nature of science.

The most important point in this study is that the teaching of the nature of science will be easier and more useful through using the box activities with relating them to the science curriculum.

In this type of activities, students must be active to produce solutions and explanations with creating an adequate understanding about the nature of science. Especially, if the concepts of the nature of science in activity applications are directly emphasized to the students, it is better for students to develop students' views about the nature of science $[21,34]$. To ensure that student's developan enough understanding of the nature of science, it is important to use the work sheets after application of the activities.

When evaluated according to the answers given by the students to the work sheets, it can be said that teaching with box activities carried out makes an important contribution to the learning of the opinions of the students that the imagination and creativity are important in the production of scientific knowledge.

When the answers given by the students to the question of "How do you think an event that scientists can observe but do not know the details?" are examined, the students stated that they used imagination and creativity, made ideas and made predictions while explaining an event that scientists could observe but did not know the details.

\section{CONCLUSION AND SUGGESTIONS}

It is possible to say that more box activities can be designed for the use of science teachers in terms of teaching science with emphasizing the nature of science. Work sheets are vital parts of the eactivities to assess students' learning of the nature of science concepts. Following a certain procedure in application of the box activities is necessary for the success of the activity by the users or teachers.

The activities prepared in the study can be designed in a similar way for each unit of science course and different grade levels. It is very important to prepare the nature of science in order to process lessons by teaching the nature of science.

Since the students work together and exchange ideas, it is beneficial for students to learn the concepts related to the nature of science. It is also recommended that teachers take the activities within the scope of the lesson plan and make research and preliminary studies on the subject. Sample activities can also be given in the training programs.

Int. J. Eval. \& Res. Educ. Vol. 8, No. 2, June 2019: 221 - 228 


\section{ACKNOWLEDGEMENTS}

This work was supported by the Ahi Evran University Scientific Research Projects Coordination Unit (Project Number: EGT.A4.17.008). This study was a part of Master Thesis. This study is presented as an oral presentation at the II. International Scientific and Vocational Studies Congress in 5-8 June 2018, Ürgüp, Turkey.

\section{REFERENCES}

[1] Bell, R., Abd-El-Khalick, F., Lederman, N. G., Mc Comas, W. F., \& Matthews, M.R. "The nature of science and science education: A bibliography," Science and Education, vol. 10(1-2), pp. 187-204, 2001.

[2] Coben, D., "Mathematics or common sense? Researching invisible mathematic sthrough adults mathematics life histories," Perspectives on Adults Learning Mathematics, Mathematics Education Library, vol. 21(3), pp.53-66, 2000.

[3] Lederman, N. G. \& Zeidler, D. L., "Science teachers' conceptions of the nature of science: Do they really influence teacher behavior?," Science Education, vol. 71(5), pp.721-734, 1987.

[4] American Association for the Advancement of Science (AAAS), "Project 2061: Benchmarks for Science Literacy," Oxford University Press, New York, 1993.

[5] Abd-El-Khalick, F., Bell, R. L. \& Lederman, N. G., "The nature of science and instructional practice: Making the unnatural natural," Science Education, vol. 82(4), pp. 417-437, 1998.

[6] Bora, N. D., "Investigating science teachers' and high school students' views on the nature of science in Turkey," PhD. thesis, Gazi University Institute of Educational Sciences, Ankara, 2005.

[7] Kapucu, M. S., "Influence of using documentary movies in the course of science and technology on elementary school 8th grade students' achievements in the subjects of cell and force and on their views about the nature of science," PhD. Thesis, Hacettepe University, Social Sciences Institute, Ankara, 2013.

[8] Khishfe, R. \& Abd-El-Khalick, F., "Influence of explicit and reflective versus implicitinquiry-oriented instruction on sixth graders' views of nature of science," Journal of Research in Science Teaching, vol. 39(7), pp. 551-578, 2002.

[9] Küçük, M., "A study toward teaching the nature of science for seventh grade primary students," PhD. Thesis, Karadeniz University, Science Institute, Trabzon, 2006.

[10] Lederman, N. G., "Teachers' understanding of the nature of science and class room practice: Factors that facilitate or impede the relationship," Journal of Research in Science Teaching, vol. 36(8), pp. 916-929, 1999.

[11] Lederman, N. G., Abd-El-Khalick, F. Bell, R. L.\& Schwartz, R., "Views of nature of science questionnaire: Toward valid and meaning ful assessment of learners' conceptions of nature of science," Journal of Research in Science Teaching, vol. 39(6), pp. 497-521, 2002.

[12] Schwartz, R. S. \& Lederman, N. G., "It's the nature of the beast: The influence of knowledge and intentions on learning and teaching nature of science," Journal of Research in Science Teaching, vol. 39(3), pp. 205-236, 2002.

[13] Ryan, A. G. \& Aikenhead, G. S., "Students' preconceptions about the epistemology of science," Science Education, vol. 76(6), pp. 559-580, 1992.

[14] Abd-El-Khalick, F., "The influence of a philosophy of science course on preservice secondary science teachers' views of nature of science," Proceedings of 2002 The Annual International Conference of The Association for the Education of Teachers in Science, 2002.

[15] Abd-El-Khalick, F., Bell, R. B. \& Schwartz, R. S., "Views of nature of science questionnaire: Toward valid and meaning ful assessment of learners' conceptions of nature of science," Journal of Research in Science Teaching, vol. 39(6), pp. 497-521, 2002.

[16] Bilen, K., "A sample application in nature of science course: the game card exchange," Mustafa Kemal University Journal of Social Sciences Institute, vol. 9(18), pp. 173-185. Retrieved from http://sbed.mku.edu.tr/article/view/1038000269/1038000140, 2012.

[17] Erdoğan, M. N. \& Köseoğlu, F., "The teaching of the nature of science with an open-minded approach integrated into the subject of chemical equilibrium," Journal of Theory \& Practice in Education (JTPE), vol. 11(2), pp. 717-741. doi: 10.17244/eku.10274, 2015.

[18] Köseoğlu, F., Tümay, H., \& Budak, E., "Paradigm changes about nature of science and new teaching approaches," Journal of Gazi Education Faculty, vol. 28(2), pp. 221-237. Retrieved from http://gefad.gazi.edu.tr/article/view/5000078593/5000072814, 2008.

[19] Tümay, H. \& Köseoğlu, F., "Promoting pre-service chemistry teachers' understanding of nature of science with argumentation focused activities in science," Journal of Gazi Education Faculty, vol. 30(3), pp. 859-876, Retrieved from http://gefad.gazi.edu.tr/article/view/5000078485/5000072706, 2010.

[20] Abd-El-Khalick, F. \& Lederman, N. G., "Improving science teachers' conceptions of nature of science: a critical review of the literature," International Journal of Science Education, vol. 22(7), pp. 665-701, 2000.

[21] Akerson, V. L. \& Abd-El-Khalick, F., "How should I know what scientists do?- I am just a kid": fourthgradestudents' conceptions of nature of science," Journal of Elementary Science Education, vol. 17(1), pp. 1-11, 2005.

[22] Driver, R., Leach, J., Millar, R. \& Scott, P., "Young people'simages of science," Open University Press, Buckingham, 1996.

[23] Lederman, N. G., "Students' and teachers' conceptions about the nature of science: A review of the research," Journal of Research in Science Teaching, vol. 29, pp.331-359, 1992. 
[24] Pomeroy, D., "Implications of teachers' beliefs about the nature of science: Comparison of the beliefs of scientists, secondary science teachers and elementary teachers," Science Education, vol. 77, pp. 261-278, 1993.

[25] Ministry of National Education (MEB), Primary education institutions (primary and secondary schools) science courses (3rd, 4th, 5th, 6th, 7th and 8th grades) science curriculum, Ankara, 2013.

[26] Doğan, N. \& Özcan, M. B., "Influence of historical perspective approach on 7th grade students' views about nature of science," Ahi Evran University Kırşehir Faculty of Education Journal, vol. 11(4), Special Issue, pp.187-208, 2010.

[27] Şener Çanlı, D., "Effect of the nature of science activities on 7th grade students' views of science (Kurşehir sample)," Master Thesis, Kırşehir Ahi Evran University, Science Institute, Kırşehir, 2018.

[28] Yıldırım, A. \& Şimşek, H., "Qualitative research methods in the social sciences," 5th press, Seçkin Publishing, Ankara, 2005.

[29] Doğan, N., Çakıroğlu, J., Bilican, K., \& Güngören, S. Ç., "Nature of science and teaching," Pegem Academy, Ankara, 2014

[30] Lederman, N. G., \& Abd-El-Khalick, F., "Avoiding de-natured science: Activities that promote understandings of the nature of science," In W.F. McComas (ed.), The nature of science in science education: Rationales and strategies, Kluwer Academic Publishers, pp. 83-126, Boston, 1998.

[31] Şener Çanl1, D. \& Afacan, Ö., "Box activities about teaching the nature of science for $7^{\text {th }}$ grade middle school students," Natural Science Education, vol. 15(1), pp. 38-51, 2018.

[32] Akerson, V. \& Donnelly, L. A., "Teaching nature of science to K-2 students: What understandings can the yattain?," International Journal of Science Education, vol. 32(1), pp. 97-124, 2010.

[33] Kaya, G., "The influence of an explicit reflective approach on elementary students' views of nature of science and their academic achievements about the concept of light," Master Thesis, Hacettepe University, Social Sciences Institute, Ankara, 2011.

[34] Akerson, V. L. \&Volrich, M. L., "Teaching nature of science explicitly in a first grade internship setting," Journal of Research in Science Teaching, vol. 43(4), pp. 377-394, 2006.

Int. J. Eval. \& Res. Educ. Vol. 8, No. 2, June 2019: 221 - 228 